\title{
Peer group, educational distinction and educational biographies
} Heinz-Hermann Krüger, Sina-Mareen Köhler, Nicolle Pfaff and Maren Zschach Childhood 2011 18: 477 originally published online 19 August 2011

DOI: $10.1177 / 0907568210394880$

The online version of this article can be found at:

http://chd.sagepub.com/content/18/4/477

\author{
Published by: \\ (9)SAGE \\ http://www.sagepublications.com \\ On behalf of: \\ Norwegian Centre for Child Research
}

Additional services and information for Childhood can be found at:

Email Alerts: http://chd.sagepub.com/cgi/alerts

Subscriptions: http://chd.sagepub.com/subscriptions

Reprints: http://www.sagepub.com/journalsReprints.nav

Permissions: http://www.sagepub.com/journalsPermissions.nav

Citations: http://chd.sagepub.com/content/18/4/477.refs.html

\author{
>> Version of Record - Nov 18, 2011 \\ OnlineFirst Version of Record - Aug 19, 2011 \\ What is This?
}


Peer group, educational distinction and educational biographies
I8(4) 477-490

(C) The Author(s) 2011 Reprints and permission: sagepub. co.uk/journalsPermissions.nav DOI: $10.1177 / 0907568210394880$

chd.sagepub.com

\title{
Heinz-Hermann Krüger
}

Martin-Luther-Universität Halle-Wittenberg, Germany

\section{Sina-Mareen Köhler}

Leibnitz-Universität Hannover, Germany

\author{
Nicolle Pfaff \\ Georg-August-Universität Göttingen, Germany
}

\section{Maren Zschach}

Martin-Luther-Universität Halle-Wittenberg, Germany

\begin{abstract}
The article presents selected results of a reconstructive study on the significance of the peer group for children's educational biography. Based on the analysis of qualitative interviews and group discussions with c. II-year-old children from different educational milieus in Germany it is first shown how, in general, groups of friends in different social contexts exert influence on the children's school careers. In a second part, the text pursues the question of how children produce social inequality themselves, what processes of distinction they practise and on the basis of which traits and criteria. Thereby the study demonstrates that internal and external distinction practices refer to entirely different concepts of achievement.
\end{abstract}

\section{Keywords}

case studies, distinction, peer group, school careers, social inequality

\section{Corresponding author:}

Nicolle Pfaff, Georg-August-Universität Göttingen, Pädagogisches Seminar, Baurat-Gerber-Str. 4/6, 37073

Göttingen, Germany.

Email:npfaff@gwdg.de 


\section{Research on peer groups and school achievement in preadolescent childhood}

Studies on cliques have gained distinctly in significance in childhood- and youth research over the past decade, since the socializing and identity-forming effect of the peer group was first revealed by sociological and development psychological investigations on early childhood (e.g. Sullivan, 1983; Younnis, 1980). Younnis (1980), for example, indicates that children co-construct their social worlds for each other among themselves, that they develop world- and self-interpretations in interaction with each other. Fend (1990) attributes a distinct identity-forming effect to the age group in the phase of youth (Coie et al., 1990; Larson and Richards, 1991; Ryan, 2001) and in German socialization research a debate has flared up about whether children and adolescents, contrary to the emphasis on family and school as central socialization influences until recently, do not rather socialize themselves (Bauer, 2002; Zinnecker, 2000). Within the sociologically oriented childhood research in past decades the focus was mostly on friendships between children, their social constitution and the concrete practices of peer groups. This includes peers' gender-related, recreational and scholastic activities. In the context of this article, which aims to examine the distinction processes with respect to education within age groups, studies on peer groups' social constitution and on education-related practices and activities are of special interest. These two areas of research are briefly introduced in the following paragraphs.

As regards the social and achievement-related constellation of children's peer groups, various investigations indicate that such peer groups are usually homogeneously constituted with respect to achievement (e.g. Damico, 1975) and class (Elliot et al., 2006 Hallinan, 1995).

It is here usually presumed that the inclusion of peers influences the state of scholastic achievement. The early work of Hargreaves (1967) and Lacey (1970) points out that peer norms oriented themselves towards a pro-anti continuum with respect to school achievement and had an influence on pupils' achievement levels. In a developmental psychologically oriented quantitative study on the school achievements of young people, Bradley (1979) highlighted that clique norms on academic achievement led to achievements on the part of children that were above or below their expected achievement spectrum (Bradley, 1979: 25). In this context such investigations are also to be mentioned that show that, for the sake of better peer integration, high achieving pupils often make an effort either to conceal their achievements or to describe them as natural talent (e.g. Breidenstein and Meier, 2004; for a summary of this, see Zschach, 2008b). Cross-cultural studies on this topic indicate nationally specific ways to treat the 'nerd' stigma (e.g. Juvonen and Murdock, 1995; Pelkner and Boehnke, 2003).

On the basis of our study material it came to light that children tend to address school achievements in their peer groups with respect to other groups or teachers, rather than comparing group members to one another. In some groups levelling tendencies can also be found, where apparently similar results are portrayed in the scholastic area in spite of different achievements, while yet other groups tend to treat the topic as a taboo (Zschach, 2008b). Distinction processes related to school achievement, as we investigate them more closely in this article, appear at first to be more strongly directed to other pupil groups than within one's own peer group. 
Peer effects on the individual achievements of adolescent pupils were also examined in current school studies. In a quantitative analysis by Stecher (2001: 315) it became clear that the risk of delinquency was distinctly higher in adolescents in cliques, but their sense of their own scholastic abilities was not negatively influenced by this. From current quantitative reanalyses of PISA data from the year 2000, not only general connections between the peer cultures of schools and their achievement results were investigated (Baumert et al., 2006). Meier (2004) also examined mutual relationships between the inclusion in different extra-scholastic peer groups and achievement in school subjects. It became clear from his research that membership in cliques with an aggressive orientation coincides with rather negative scholastic achievements, while membership in reading-oriented circles of friends furthers such achievements somewhat (Meier, 2004: 197).

In this present article the connection between peer inclusion and school achievement is examined with respect to two aspects: first, the relation between individual children's education-related orientations and those of their peer groups (for more detail see Krüger and Deppe, 2008a, 2008b), and second, with respect to achievement-related distinction processes produced by peer groups vis-a-vis other children. But before this, the next two sections provide an introduction to the research project upon which the presentation of results is based and to some important specifics of the German educational system.

\section{Peer groups and scholastic selection - the research project}

The results presented here come from the first phase of investigation of a research project planned as a reconstructive longitudinal study on the significance of the age group for children's and adolescents' educational careers (Krüger et al., 2008b). The study enquires into school achievement expectations and selection processes within peer groups and their effects on the course of individual children's scholastic education. At the same time the significance of social origin and school achievement for the development and constitution of peer groups is also examined.

Thus, the research project lies at the interface between childhood and school research, which for the most part in Germany, unlike for example in the USA, have hitherto remained as separate areas of enquiry (James, 2004; Qvortrup, 2000, 2005). The study stands theoretically in the tradition of sociologically oriented childhood research (James and James, 2005; Qvortrup et al., 2008), which understands children as makers of their own biographies as well as of their environments, and starting from this assumption, enquires into the interpretations that children bring to themselves, their actions and their life-worlds (Belsky et al., 1993). At the same time the project also draws on a knowledgesociological milieu concept in the praxeological tradition (Mannheim, 1982, 1993 [1923]) and brings into focus social groups' action-guiding orientations in the sense of Bourdieu's habitus concept.

In accordance with these theoretical principles, the study is based on a reconstructive approach (on the methodical structure of the project, see Krüger and Pfaff, 2008). Thus, in the first phase of the project, in the years 2006 and 2007, qualitative interviews were held with nearly 60 children aged roughly 11 years. From this sample group, discussions with the children's friends in and out of school, ethnographies in different life-worlds and videographies of select practices were realized for a 
subsample of 10 children. These multifarious data were then prepared and subjected to a documentary interpretation which aims to reconstruct the implicit or tacit knowledge that underlies everyday practice and orients habitualized actions independently from subjective intentions and motives (see Bohnsack and Nohl, 2003; Bohnsack et al., 2010). The method of documentary interpretation consists of four steps, beginning with a thematic overview of the material, the interpretation and classification of relevant topics, the decodification of orientation frames based on the analysis of the discursive construction of topics and finally the comparative analysis, which highlights the specifics of a certain individual or group (see Mannheim, 1982, 1993 [1923]; see Bohnsack, 2009; Bohnsack et al., 2010). In the third section of this article, against a description of the German school system, brief biographic portraits are presented based on biographic facts given by the children during the interviews; these are then followed by selective reconstructions of interview and discussion data in the fourth section.

However, the analysis focused primarily on reconstructing the individual frame of the child's orientation from the biography as told by the child. In a second step, this frame was placed in relation to adjustment to the collective orientations that exist in the child's peer groups with respect to the topics school, study and friendship. In this way, at the end of the first phase of the longitudinal study, patterns could be shown in the role of peer groups for the children's scholastic and educational biography (Krüger and Deppe, 2008a). The first pattern to be observed, in a highly cultural and educationally oriented social context, was a homology between good school achievement and a high achievement orientation among friends. Education functions here both in the scholastic and in the peer context as a framework for processes of social distinction (Böhme, 2003; Brake, 2006). A second pattern revealed that a homology also exists between scholastic and extra-curricular, peer-oriented achievement. Here, though, both through school and athletic achievements a social advancement is to be expected. In a third pattern, the peer group's orientations, which include no explicit achievement orientation, stand independently of an individual's higher educational ambitions, and are thus completely detached from the educational ambitions of each individual. In the fourth pattern, a pragmatic educational orientation that ensures the attainment of a socioeconomic status meets a peer group that can be described as dissociated from school, one in which school achievement plays no special role (Krüger and Deppe, 2008a). In the last case, to which already several references have been made in the literature (e.g. Bietau, 1989; Willis, 1977), the peers appear as high-risk capital, insofar as they increase the danger of nonachievement-oriented children's educational failure through practices and orientations unrelated to education.

However, in this article we focus on the practices of social distinction in different segments of the German school system. Thereby, educational distinction as an object of cultural practices in the peer context has a specific significance and different functions for the school career in the sense of the patterns introduced briefly above.

But beforehand, several idiosyncrasies of the German school system are addressed, a system which itself, according to a number of relevant research results, contributes decisively to a strong reproduction of educational inequality through an early selection of pupils (e.g. Marks, 2005). 


\section{Educational system for I I-year-old pupils in Germany}

In Germany the organization of the education system falls within the jurisdiction of each of the 16 states, so that differences between school forms exist within the state. In most Länder, children attend an elementary school together until the end of the 4th grade, at which time an achievement-based selection of the pupils takes place for the next school type. The subsequent secondary school system normally distinguishes between the Gymnasium, which leads to the Abitur and entitles the graduate to study at a university, and the lower qualifying school forms, the six-year Realschule and the five-year Hauptschule, the former offering a mid-level, and the latter only a basic graduation certificate. As an alternative, integrated school systems are present in some states that encompass different courses of education.

This early differentiation of the student body along these different paths is currently under fire, due to international comparative studies on successful study (e.g. Baumert et al., 2006; Fertig, 2003; OECD, 2005) but also on educational participation (e.g. Marks, 2005). It contributes to a high reproduction of educational inequality, as relevant macrosociological enquiries show (e.g. Becker, 2003; Sünker, 2004; Vester, 2004). This effect is also apparent from a microsociological perspective on the children we studied (Krüger and Deppe, 2008a; Zschach, 2008b) and is described here, using several selected brief case portrayals. We also sketch the socioeconomic and educational status of each child's family and the most important stations in the children's educational biography, commenting on these sketches in greater detail later on in this article.

As the daughter of a historian at the University of Leipzig and of a university graduate who presently works as a housewife, Nadja Tafel comes from a highly cultural social milieu (for a detailed case portrayal, see Deppe, 2008). Her scholastic and educational career began after kindergarten with her admission to a private school for creative children. There she skipped a grade due to her excellent achievements. Nadja also participates in several other educational activities in diverse musical and Christian contexts, e.g. in violin and piano lessons, participation in an adult choir or confirmation class. Accordingly, it is beyond question for Nadja and her family that she will take and pass an entrance exam ${ }^{1}$ at a Christian run Gymnasium with high standards of achievement (Deppe, 2008). Nadja's ideas for the future, an academic degree, also correspond to her school career until now, although she is not yet decided on any specific profession.

A similarly successful school career has been pursued by Tim Hoogland, who comes from a less highly cultural milieu (for a detailed account, see Deinert, 2008). Nevertheless, his parents, his father a medical representative and his mother a physical therapist, also have higher degrees (German qualifications necessary for certain professions). After kindergarten, Tim first attended a public elementary school in a small town just on the outskirts of the city where he lived with his parents. There he also began football practice, which he continues even today, and where his excellent achievements have earned him a place in a training camp of the German Football Association (DFB). That Tim's parents are interested in special scholastic support for him, and that they foster in him further ambitions, can be seen in that after a very good mark at the end of elementary school, Tim, the best pupil in his class, took entrance exams for two Leipzig Gymnasia with especially high achievement standards. He is currently attending the same school as Nadja and would like to become a scientist. 
In contrast to Nadja's and Tim's school careers are Kevin's and René's educational biographies. After kindergarten, Kevin Ottnitschke, the son of a middle-class construction company owner and the manager of a bar, first attended the rural elementary school in his hometown (for a detailed account, see Zschach, 2008a). That Kevin's parents have no higher ambitions for him that might be realized via education is apparent from their choice of a secondary school for their son. Kevin attends the secondary school in the town where he lives and wishes to leave with a mid-level certificate. At the same time, a strong economic orientation at home leads the boy especially to appreciate life-worldly knowledge, which he learns mostly playing in the natural outdoors and travelling abroad with his parents. Vis-a-vis these activities, school is rather unappreciated (Zschach, 2008a: 143). As he wished to pursue a career in professional soccer, his athletic achievements are more important to him than his school achievements.

Yet less favourable conditions for a successful school career are those of René Leuter, whose parents place no high educational demands on their son (for a detailed account, see Köhler, 2008). René's parents and stepfather took lower certificates, and were unemployed or working at a trade, as a bookbinder, and in a hardware store. Due to developmental problems, René attended a pre-school prior to his admission to a public elementary school and repeated a grade in elementary school. Since the end of elementary school, René has been attending a (lower qualifying) Hauptschule in his district, which he sees as a setting for peer culture rather than for education (see Köhler, 2008). Beyond his school career René aspires to a position at a grocery discount store where his grandfather is employed.

In the cases briefly introduced here it is already clear how closely connected the pupils' sociodemographic origin and the educational ambitions relayed to them in the familial context are to the educational paths they follow. Both the low educational mobility (Vester, 2004) and the strong socioeconomic homogeneity of individual schools' student bodies (Solga and Wagner, 2007) in the highly differentiated school system in Germany are clearly felt. The children themselves are also already aware of this effect of social student body homogenization, and on this basis they play out practices of social distinction against the background of various patterns of interpretation. But before we come to the different practices of distinction of the children studied, the central results of our study first sketch patterns of peers' significance for the educational biography.

\section{On the practice of social distinction in peer groups in the planning of an educational biography}

In spite of similar social positions, in the peer contexts of Nadja and Tim, on the one hand, and of Kevin and René, as pupils in lower to mid-level school forms, on the other hand, quite different constructions of school achievement, distinction and juvenile leisure practices were noticeable.

\section{Distinction and recognition in educational biographies and peer groups in the mid- to lower level types of school}

Looking at the children and their groups who are not to be counted among the 'winners' in the scholastic selection process, the first thing that occurs to one is that the 
reconstructed individual and collective orientations are more ambivalently structured than implied by the less ambiguous results of such studies as Willis (1977) or Watts (2001), for example. First of all, it became clear in the group discussions that in the cases studied here, i.e. Kevin and René, each with his respective group of friends, a tendency to dissociate themselves from classmates with above average achievements showed no direct connection to educational motivation or their general ideas about a school career. Distancing themselves from more successful pupils attending the Gymnasium is hence not necessarily connected with a blanket disinterest, or with the rejection of school as an institution, as we shall demonstrate. Instead, these discourses contribute to a process of coming to terms with experiences of scholastic failure in the course of selection processes, such that boys such as Kevin and René protect their own self-esteem in the course of arranging their lives, or their self-conception, developing realistic future expectations with respect to their professional curricula.

Thus, for example, in Kevin's group, no out-group differentiation (Brüß, 2002; Tajfel, 1981 ) occurs. The two boys' response to our question about their relation to other groups lacks any distinction in the sense of a stigmatizing or dissociation. Especially Kevin, whose family disposes of a relatively large quantity of economic capital for the area, emphasizes: 'in our clique it ain't jus' kids from families that have a whole lotta money, an' it ain't jus' kids from families that ain't got no money at all, neither with us, we take anyone (I: mm-h) well we don' take jus' anyone, but we don' care too much about t' money' (GD: Kevin, 389-393). ${ }^{2}$ This is just as valid for school achievement evaluations, which are expressed in corresponding grades. Kevin's peer group, whose members achieve average to good school grades, emphasizes here that these factors play no role in the acceptance into his clique: 'in ou-our clique it's not about money an' it ain't a-(loud noise) about grades' (GD: Kevin, 687-688). Still, the boys are not blind to the differences in school achievement; they are rather all too well aware that the girls in their class generally have worse grades in written work. Here the distinction also serves to emphasize preadolescent dissociation vis-a-vis the opposite sex. The girls in their class are portrayed in this context as 'distant others' and under the label 'extreme cases' (GD: Kevin, 1213) the boys deny their budding interest in girls. If such a comparison of achievements does not exclusively serve a pejorative gender-specific distinction, it is nevertheless significant for the group's collective orientation, as a failing grade receives the special attention of masculine classmates.

In the case of René and his friend Paul there is a high degree of uniformity in their attitude towards school, while discrepancies vis-a-vis the concrete manifestation of this attitude are clearly visible, both individually and collectively. René identifies himself explicitly with the Hauptschule with his statement: 'this kin'a' - this school, it's my kin'a' school' (I: René, 281). A distinction vis-a-vis adolescents who attend other types of schools is based not on their cognitive capabilities, but on the portrayal of their behaviour exclusively outside school: 'Rm: Realschule kids [...] big mouth, nah (.) but nothin' to back it up; Pm: that's the way it is usually with Realschule kids they all got a big mouth except my half-brother, my half-brother, you know, at least he packs a little gumption' (GD: René, 477-479). Like Kevin, the boys also connect their rejection of individual pupils to the latter's deficits, although they practise a strongly distinguishing demarcation. And just as in Kevin's case, this also applies to the opposite sex, as is apparent from the following passage: 'these two girls from our old class, they were a 
couple o' real brown nosers. And now they're at Gymnasium, they always got good grades jes' 'cause they always brown nosed' (GD: René, 24-27). School has, in their opinion, a great general significance, a significance specifically connected to good marks, as they emphasize in their responses to the corresponding questions at several points in the discussion. Their positions are justified with such arguments as: 'cause we both need 'em [good marks] too, 'cause if we get bad grades, then we don't get so far later on' (GD: René, 424-425). René and Paul, however, unlike Kevin's group, hardly place this collective orientation in connection with their classmates' scholastic achievements. An explicit effort to distance themselves from two of the best achievers in their class only occurs once in connection with the completion of a homework assignment that all the other classmates rejected as impossibly long, as Paul's statement reveals: 'But Victoria didn't really get it either', whereupon René adds 'yeah, well, Victoria's a brown noser, too, with Stefanie, dude. Teacher's pet' (GD: René, 309-310). Their practised distinction is directed at nerds (Breidenstein and Meier, 2004; Juvonen and Murdock, 1995), who are stigmatized as non-peer-oriented and interested only in their own achievements, in contrast to that of Kevin's group, where the distinction is primarily vis-a-vis the opposite sex.

Kevin and his friends are wont to produce unity within the group using similar methods to those of René and his friend. On the other hand, their achievement orientations are directed at an immediate comparison with their schoolmates, in the course of which a demarcation vis-a-vis poorer achievers and a striving towards better results in school can be reconstructed. In this regard the estranged attitude towards school with respect to rhetoric and actionism primarily displays the function of producing unity within the group. Through the orientation towards the other kids in their class, the risk potential of failure with respect to educational biography is reduced, while René and his friend Paul place less emphasis on such standards for comparison. Indeed, their school-related orientations, often expressed at the level of wishes and positive resolutions, appear less promising.

\section{Acknowledgement and distinction of peer groups in the Gymnasium segment}

The peer contexts to be examined here are of Nadja Tafel's (for a detailed account, see Deppe, 2008) and Tim Hoogland's (for a detailed account, see Deinert, 2008) extrascholastic friendships; most of their friends attend a Gymnasium. Common structured and informal leisure time activities are the basis of the peers' shared realm of experience. Furthermore, football provides the framework for both groups within which others in their age group are experienced as opponents. The demarcations that result from this rivalry, however, are directed at quite different aspects and manifest themselves in the boys' and girls' remarks on their distinguishing characteristics. In contrast to René's and Kevin's practices of distinction and dissociation as described in the preceding paragraphs, this does not only take place in the school arena, but does relate to the school career, as performance and educational standards are generally conceived of together.

It is clearly visible from the discussion with Nadja and her friends that they distinguish themselves from others and at the same time extol themselves with respect to 
certain interests and activities, 'we all believe in God' or 'we're pretty athletic, and (...) we're very musically inclined' (GD: 183-185) and based on specific properties and educational status 'we're just awesome' (GD: 77) or 'we all go to a Gymnasium' (GD: 173). Just by addressing the criteria for distinction in an explicit, differentiated and dynamic manner, Nadja's peer group differs quite distinctly from Tim's. Furthermore, the girls not only discuss differences to other groups, but also to each other. The following passage illustrates this external and internal demarcation:

Tw: let's take, as a crass example,the Reudnitzers; the Reudnitzers are (.) to put it plainly, stupid

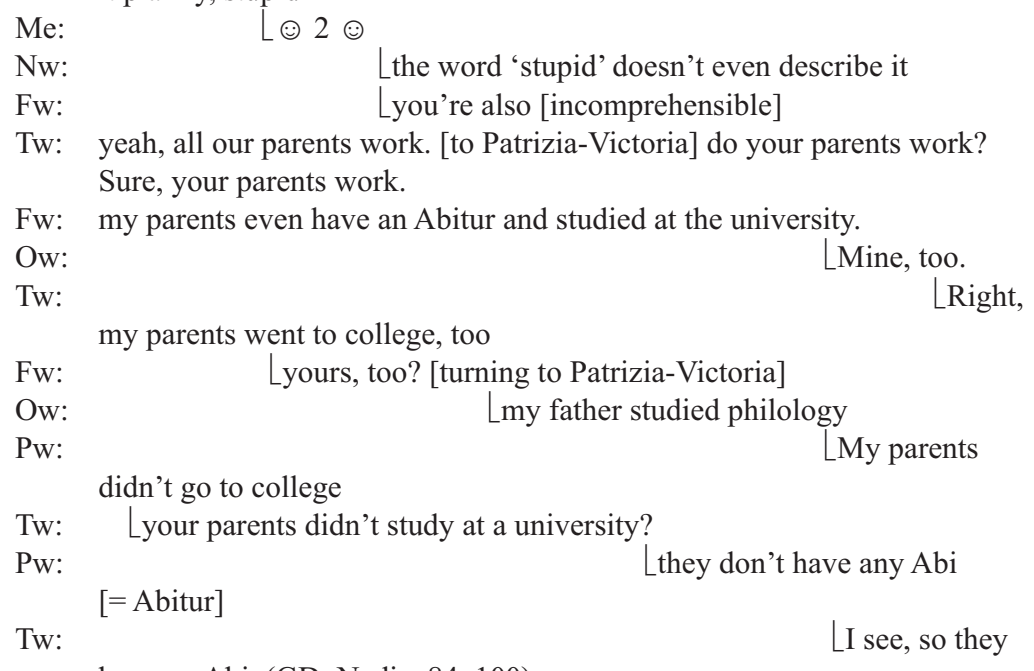

have no Abi. (GD: Nadja, 84-100)

Patrizia-Victoria's special position within the group is clear here. First it is investigated whether she differs from the others with respect to her parents' educational status. In the further course of the discussion the girls relate at length their parents' academic careers with all their doctorates, leaving Patrizia no opportunity to participate in the conversation. This indirect exclusion is apparent in other places in the discussion, e.g. when Patrizia's hometown or religious denomination is at issue. This behaviour can be described as an internal distinction practice with recourse to social status. Indications of the external distinction practice are also apparent in the passage cited. First the Reuditzners are degraded with respect to their alleged poor cognitive capabilities (Reudnitz is an area with high poverty and unemployment rates, where more socially disadvantaged families live). It is through this statement that the girls come to speak about their parents' status. All of them are gainfully employed and, with one exception, all have completed an academic curriculum. A group identity is constituted via this distinction to others through the parents. With regard to the Reudnitzers' status, the external demarcation becomes more distinct.

Among Tim's friends, in contrast, there are no criteria for demarcation based on social status. Their athletic opponents are degraded in other ways: 
Iw: and you also meet other teams, right? How is that then?

$\mathrm{Mm}$ : $\quad \mathrm{L}_{\text {yeah the's another }}$ really bogus team (.) we we rumble widdem alla time, ' cause'ey they go out for blood (.)

Tm: $\quad L$ who d'ya mean, Miltiz?

Mm: $\quad$ L yeah, Miltiz (.) two o'dem dey always

foul really bad an- an' they always kn- knock me and Tim down (.) 'cause I shot a goal against them in the gym (.) 'n' dey were so pissed, dey took the knee an (.) rammed 'is knee in my gut (.) one of 'em

$[\ldots]$

Dm: wanna see Borsdorf on the bottom, ya gotta turn the chart upside down

$[\ldots]$

Iw: what do you think makes you as a group different from the others

Mm: (.) we always stick together

Tm:

?m:

Mm: yeah (GD: Tim, 5-41)

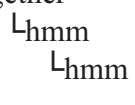

It is made plain enough that this peer group, too, prefers to distinguish itself from a 'lower' group. The only point of comparison here, though, is athletic prowess. These distinction criteria do not concern character deficits, such as those cited by Kevin and René, nor the educational or social status cited by Nadja and her friends. Tim's peers construct a negative counter-horizon by accusing them of poor sportsmanship. Accordingly, they understand themselves as fair and considerate players. A just victory is achieved through good athletic achievement. Furthermore, they describe their group not in terms of traits that elevate any individual, but emphasize the quality of their relationship to one another.

As one can see, the distinction-related orientations and practices of Nadja's and Tim's peer groups both focus on the failures or low performance levels of their opponents. The decisive difference is, on the one hand, the area of achievement itself, i.e. sports vs. education, and on the other, the ideas about the way to success. Distinction in the classical sense cannot be reconstructed with regard to the group discussions with Tim and his friends. With the corresponding expansion of the notion of distinction, only an external distinction focused on athletic performance can be discerned here. Internal distinction processes, however, cannot be found. Instead, inclusion efforts appear that have no need of external dissociation. The fuller analysis of all the material on Tim's friends (Deinert, 2008) makes it clear that they strive for a well-functioning athletic community. Accordingly, success can be achieved through collective diligence and hard work, and can thus be influenced. At this point there appears an adjustment in Tim's individual orientation, who believes his pursuit of a university career is only achievable through personal effort. In contrast, with respect to the collective frame of orientation of Nadja's friends, it comes to light that they take higher qualifying educational degrees for granted. In this case, too, an adjustment takes place, for Nadja relates skipping a grade in her biographic narrative as nothing really special. Likewise, in the eyes of her peers it seems only 'natural' that others are only capable of lesser cognitive achievements, and can be degraded with reference to the same. This distinction practice in the narrower sense is effective as a concealed process of the (re)production of social inequality, and corresponds to the extant mechanisms of scholastic selection. 


\section{Summary and prospects}

This article has dealt with practices of social distinction in preadolescent peer groups placed in distinct segments of the highly differentiated German school system. Thereby the analysis presented two disparate modes of social distinction: in the groups examined an outward social distinction vis-a-vis other cliques within or outside school among the pupils of the high qualifying schools was oriented towards achievement-related criteria, while the cliques from lower qualifying schools, on the contrary, were rather oriented according to modes of conduct. Related to the five patterns of relevance of the peer group for the children's educational biographies, it can be stated that groups of children of the same approximate age and educational milieu mostly strive for equality and reciprocity in their internal social constellation and at the same time tend to distinguish themselves from other peer groups. Therefore they rely on shared socioeconomic and cultural belongings, school or extra-curricular achievement and shared educational attitudes. Based on these practices they pursue the social coherence between the context of family origin and educational pathways of children, which is introduced by the strong and early educational differentiation in the German school system, and thus take an active role in the reproduction of educational inequality.

\section{Funding}

The research project on which this article is based was supported by the German Research Foundation (Deutschen Forschungsgemeinschaft, DFG) (KR 1336/6-1) and realized at the Centre of School and Education Research (ZSB) of the University of Halle-Wittenberg.

\section{Notes}

1. Such entrance exams are a rare exception in Germany, occurring, for example, at independent or privately run Gymnasia, or those with an educational profile with a special athletic, musical, or natural scientific orientation.

2. The extracts from the German discussions have been translated. The system of transcription is as follows. Pauses are cited in seconds in parentheses (.), indentations signify overlaps of speakers and the smiley $;$ - shows that something is said laughing. Incomprehensible or barely understandable words are written in parentheses and the symbol [...] marks cuts in the cited part of the discussion. GD refers to extracts from the group discussions, I to extracts from interviews, and the numbers indicate line numbers in the transcript. Capital letters are used to identify speakers and small letters $\mathrm{w}$ and $\mathrm{m}$ to indicate their sex.

\section{References}

Bauer U (2002) Selbst- und/oder Fremdsozialisation: Zur Theoriedebatte in der Sozialisationsforschung. Eine Entgegnung auf Jürgen Zinnecker. ZSE: Zeitschrift für Soziologie der Erziehung und Sozialisation 22(2): 118-142.

Baumert J Stanat P and Watermann R (2006) Schulstruktur und die Entstehung differentieller Lern- und Entwicklungsmilieus. In: Baumert J Stanat P and Watermann R (eds) Herkunftsbedingte Disparitäten im Bildungswesen: Differentielle Bildungsprozesse und Probleme der Verteilungsgerechtigkeit. Vertiefende Analysen im Rahmen von PISA 2000. Wiesbaden: Verlag für Sozialwissenschaften, 95-188. 
Becker R (2003) Educational expansion and persistent inequalities of education: Utilizing subjective expected utility theory to explain increasing participation rates in upper secondary school in the Federal Republic of Germany. European Sociological Review 19(1): 1-24.

Belsky J, Lerner RM and Spanier GB (1993) The Child in the Family. New York: McGraw-Hill.

Bietau A (1989) Arbeiterjugendliche zwischen Schule und Subkultur. In: Breyvogel W (ed.) Pädagogische Jugendforschung. Opladen: Leske und Budrich, 131-159.

Böhme J (2003) Schülersubkulturen als lebenspraktischer Hiatus von Schulkulturen und Schülerbiographien. Exemplarische Rekonstruktion zur ‘enttäuschten Opposition' eines Internatgymnasiums. In: Merkens H and Zinnecker J (eds) Jahrbuch Jugendforschung. Opladen: Leske und Budrich, 155-172.

Bohnsack R (2009) Qualitative Bild- und Videointerpretation. Opladen: Barbara Budrich.

Bohnsack R and Nohl A-M (2003) Youth culture as practical innovation: Turkish German youth, 'time out' and the actionisms of Breakdance. European Journal of Cultural Studies 6(3): 367-386.

Bohnsack R, Pfaff N and Weller W (eds) (2010) Qualitative Research and Documentary Method in Educational Science: Results from Brazilian-German Cooperation. Opladen and Farmington Hills, MI: Barbara Budrich.

Bradley J (1979) Adolescent friendship cliques and academic achievement. School Psychology International 1(2): 24-31.

Brake A (2006) Das Sichtbare und das Unsichtbare. Bildungsstrategien als Strategien des Habitus. In: Büchner P and Brake A (eds) Bildungsort Familie. Transmission von Bildung und Kultur im Alltag von Mehrgenerationenfamilien. Wiesbaden: Verlag für Sozialwissenschaften, 81-108.

Breidenstein G and Meier M (2004) 'Streber'- Zum Verhältnis von Peer Kultur und Schulerfolg. Pädagogische Rundschau 58(5): 549-563.

Brüß J (2002) Akzeptanz oder Ablehnung? Vorurteile und soziale Distanz bei Jugendlichen türkischer und deutscher Herkunft. Wiesbaden: Deutscher Universitäts-Verlag.

Coie JD, Dodge KA and Kupersmidt JB (1990) Peer Rejection in Childhood. Cambridge: Cambridge University Press.

Damico SB (1975) The effects of clique membership upon academic achievement. Adolescence 10(37): $93-100$.

Deinert A (2008) Tim Hoogland - bildungsambitionierter Gymnasiast in spaßorientierter und sportlicher Peergroup. In: Krüger H-H et al. (eds) Kinder und ihre Peers. Freundschaftsbeziehungen und Schulische Bildungsbiographien. Opladen: Barbara Budrich, 78-96.

Deppe U (2008) Nadja Tafel - erfolgreiche Schülerin mit musikalischer Freundesgruppe im christlich-akademischen Milieu. In: Krüger H-H et al. (eds) Kinder und ihre Peers. Freundschaftsbeziehungen und Schulische Bildungsbiographien. Opladen: Barbara Budrich, 37-56.

Elliot AJ, Gable SL and Mapes RR (2006) Approach and avoidance motivation in the social domain. Peers Social Psychology Bulletin 32(3): 378-391.

Fend H (1990) Ego-strength development and pattern of social relationships. In: Bosma H and Jackson S (eds) Coping and Self-Concept in Adolescence. Berlin: Springer, 92-111.

Fertig M (2003) Who's to Blame? The Determinants of German Students' Achievement in the PISA 2000 Study. Essen: RWI.

Hallinan MT (1995) Patterns of cliquing among youth. In: Foot HC, Chapman AJ and Smith JR (eds) Friendship and Social Relations in Childhood, 2nd exp. edn. New Brunswick, NJ: Transaction Press, 321-342.

Hargreaves DH (1967) Social Relations in a Secondary School. London: Routledge and Kegan Paul. James A (2004) An interdisciplinary understanding of childhood. In: Pufall PB and Unsworth R (eds) Rethinking Childhood. New Brunswick, NJ: Rutgers University Press, 25-37. 
James A and James AL (2005) Constructing Childhood: Theory, Policy and Social Practice, 2nd edn. New York and Houndmills: Palgrave Macmillan.

Juvonen J and Murdock TB (1995) Grade-level differences in the social value of effort: Implications for self-presentation tactics of early adolescents. Child Development 66: 1694-1705.

Köhler S-M (2008) René Leuter - Peers als Familienersatz und Stütze im schulischen Alltag. In: Krüger H-H et al. (eds) Kinder und ihre Peers. Freundschaftsbeziehungen und schulische Bildungsbiographien. Opladen: Barbara Budrich, 177-201.

Krüger H-H and Deppe U (2008a) Mikroprozesse sozialer Ungleichheit an der Schnittstelle von Schule und Peerkontext. In: Krüger H-H et al. (eds) Kinder und ihre Peers. Freundschaftsbeziehungen und schulische Bildungsbiographien. Opladen: Barbara Budrich, 201-218.

Krüger H-H, and Deppe U (2008b) Zwischen Distinktion und Risiko - Der Stellenwert von Peers für die Bildungsbiographien von Kindern. Diskurs Kindheits- und Jugendforschung 1: 181-196.

Krüger H-H and Pfaff N (2008) Peerbeziehungen und schulische Bildungsbiografie - Einleitung. In: Krüger H-H et al. (eds) Kinder und ihre Peers. Freundschaftsbeziehungen und schulische Bildungsbiographien. Opladen: Barbara Budrich, 11-34.

Krüger H-H, Köhler S-M and Zschach M (2008a) Peergroups and selection processes within the educational system: Theoretical and conceptual framework and first results. In: Krüger H-H et al. (eds) Family, School and Youth Cultures. Frankfurt am Main: Peter Lang, 199-218.

Krüger H-H, Köhler S, Zschach M and Pfaff N (eds) (2008b) Kinder und ihre Peers Freundschaftsbeziehungen und schulische Bildungsbiographien. Opladen: Barbara Budrich.

Lacey C (1970) Hightown Grammar: The School as a Social System. Manchester: Manchester University Press.

Larson R and Richards MH (1991) Daily Companionship in late childhood and early adolescence: Changing developmental contexts. Child Development 62(2): 284-300.

Mannheim K (1982) Structures of Thinking, ed. Kettler V, Meja N and Stehr N, trans. Shapiro JJ and Weber Nicholson S London: Routledge and Kegan Paul.

Mannheim K (1993 [1923]) On the interpretation of Weltanschauung. From Karl Mannheim, ed. Wolff K, 2nd exp. edn. New Brunswick, NJ: Transaction Press, 136-186.

Marks GN (2005) Cross-national differences and accounting for social class inequalities in education. International Sociology 20(4): 483-505.

Meier U (2004) Familie, Freundesgruppe, Schülerverhalten und Kompetenzerwerb. In: Schümer G, Tillmann K-J and Weiß M (eds) Die Institution Schule und die Lebenswelt der Schüler: vertiefende Analysen der PISA-2000-Daten zum Kontext von Schülerleistungen. Wiesbaden: Verlag für Sozialwissenschaften, 187-216.

OECD (ed.) (2005) Education at a Glance: OECD Indicators. Paris: OECD Publishing.

Pelkner A and Boehnke K (2003) Streber als Leistungsverweigerer? Zeitschrift für Erziehungswissenschaft 5(1): 106-125.

Qvortrup J (2000) Macroanalysis of childhood. In: Monrad Christensen P and James A (eds) Research with Children: Perspectives and Practices. London: Routledge and Kegan Paul, 77-97.

Qvortrup J (2005) Varieties of childhood. In: Qvortrup J (ed.) Studies in Modern Childhood: Society. Agency. Culture. New York: Palgrave Macmillan, 1-20.

Qvortrup J, Corsaro WA and Honig M-S (eds) (2008) Handbook of Childhood Studies. Basingstoke: Palgrave Macmillan.

Ryan AM (2001) The peer group as a context for the development of young adolescent motivation and achievement. Child Development 72(4): 1135-1150.

Solga H and Wagner S (2007) Die Zurückgelassenen - die soziale Verarmung der Lernumwelten von Hauptschülerinnen und Hauptschülern. In: Becker R and Lauterbach W (eds) Bildung als Privileg. Erkundungen und Befunde zu den Ursachen von Bildungsungleichheit. Wiesbaden: Verlag für Sozialwissenschaften, 187-216. 
Stecher L (2001) Die Wirkung sozialer Beziehungen. Weinheim, München: Juventa.

Sullivan HS (1983) Die interpersonale Theorie der Psychiatrie. Frankfurt am Main: Fischer.

Sünker H (2004) Education and reproduction of social inequality: German politics and sociology of education. Policy Futures in Education 2(3-4): 593-605.

Tajfel H (1981) Human Groups and Social Categories. Cambridge: Cambridge University Press.

Vester M (2004) Die Illusion der Bildungsexpansion. In: Engler S and Krais B (eds) Das kulturelle Kapitel und die Macht der Klassenstrukturen. Weinheim: Juventa, 13-54.

Watts M (2001) Zur Bedeutung von Gangs und rechten Cliquen als Artikulation jugendspezifischer Aktivitäten. In: Merkens H and Zinnecker J (eds) Jahrbuch Jugendforschung 1. Opladen: Leske und Budrich, 135-162.

Willis P (1977) Learning to Labour: How Working-Class Kids Get Working-Class Jobs. Farnborough: Saxon House.

Younnis J (1980) Parents and Peers in Social Development. Chicago, IL: University of Chicago Press.

Younnis J (1984) Moral, kommunikative Beziehungen und die Entwicklung der Reziprozität. In: Edelstein W and Habermas J (eds) Soziale Interaktion und soziales Verstehen. Beiträge zur Entwicklung der Interaktionskompetenz. Frankfurt am Main: Suhrkamp, 34-60.

Zinnecker J (2000) Selbstsozialisation - Essay über ein aktuelles Konzept. ZSE: Zeitschrift für Soziologie der Erziehung und Sozialisation 20(3): 272-290.

Zschach M (2008a) Kevin Ottnitschke - schuldistanziertes Landkind mit informeller Peergroup. In: Krüger H-H et al. (eds) Kinder und ihre Peers. Freundschaftsbeziehungen und schulische Bildungsbiographien. Opladen: Barbara Budrich, 138-157.

Zschach M (2008b) Schule als Kontext und Gegenstand von Peerkultur. In: Krüger H-H et al. (eds) Kinder und ihre Peers. Freundschaftsbeziehungen und schulische Bildungsbiographien. Opladen: Barbara Budrich, 280-300. 